\title{
Transnational Activism and Free Trade. Exploring the Emancipatory Potentials of Global Civil Society
}

\author{
Celina Del Felice
}

Published online: 12 July 2011

(C) The Author(s) 2011. This article is published with open access at Springerlink.com

\begin{abstract}
This article explores the alleged emancipatory potential of global civil society as regards transnational activism to promote fair trade. It examines the case of transnational activism on European Free Trade Agreements, with illustrations from the Stop EPAs campaign and activism relating to the negotiation of an Association Agreement between the EU and Central America. It looks at how ideas of fair trade are expressed and at the process of managing diversity and searching for common messages. Activists working in North-South open and ideological diverse coalitions managed the tensions between reform and resistance for the perceived benefits of increased voice. Though transnational activism created more space for debate and action thereby promoting inclusion of different voices, some views remain marginal in the search for compromises. The analysis suggests that global civil society cannot be understood as a single entity. Rather, the emancipatory contents and meanings of global civil society are being forged through these conflicts and interactions among different groups.
\end{abstract}

Résumé Cet article est une étude du potentiel supposé d'émancipation de la société civile mondiale pour ce qui a trait à l'activisme international en faveur de la promotion du commerce équitable. Il examine les arguments de l'activisme international sur les Accords européens de libre échange, et s'appuie sur des exemples tirés de la campagne Stop EPA et de l'activisme relatif à la négociation d'un pacte d'association entre l'Union Européenne et l'Amérique centrale. Par ailleurs, il s'intéresse à la manière dont les idées de commerce équitable sont exprimées ainsi qu'au processus de gestion de la diversité et de recherche de messages communs. Les activistes travaillant du nord au sud au sein de coalitions

C. Del Felice $(\bowtie)$

Centre for International Development Issues Nijmegen, Radboud University,

Thomas van Aquinostraat 4, 6525 GD Nijmegen, The Netherlands

e-mail: c.delfelice@maw.ru.nl

URL: www.ru.nl/cidin 
ouvertes aux idéologies diverses ont su maîtriser les tensions existantes entre réforme et résistance, afin d'en retirer les bénéfices perceptibles d'une voix plus influente. Bien que l'activisme international ait ouvert un espace plus vaste pour le débat et l'action, favorisant de ce fait l'inclusion d'opinions différentes, certaines conceptions demeurent marginales quant à la recherche de compromis. L'analyse suggère que la société civile mondiale ne peut être comprise comme une entité unique. Mais plutôt, que le contenu et la signification d'une émancipation de la société civile mondiale se développent grâce à ces conflits et interactions entre ces différents groupes.

Zusammenfassung Dieser Beitrag untersucht das angebliche emanzipatorische Potential der globalen Bürgergesellschaft mit Hinblick auf den transnationalen Aktivismus zur Förderung des freien Handels. Es wird der transnationale Aktivismus im Rahmen europäischer Freihandelsabkommen mit Illustrationen der StopEPAKampagne und des Aktivismus in Bezug auf die Verhandlung eines Assoziierungsabkommens zwischen der EU und Mittelamerika behandelt. Der Beitrag untersucht, wie die Vorstellungen des freien Handels ausgedrückt werden und analysiert das Verfahren zum Umgang mit Diversität und zur Suche gemeinsamer Botschaften. In Nord-Süd tätige Aktivisten lösen Spannungen zwischen Reform und Widerstand für die wahrgenommenen Vorteile eines vermehrten Mitspracherechts aus, während ideologisch diverse Koalitionen die Spannungen bewältigten. Obwohl der transnationale Aktivismus mehr Raum für Diskussionen und Handlungen geschaffen hat und somit die Berücksichtigung verschiedener Meinungen fördert, bleiben einige Ansichten bei der Suche nach Kompromissen von nur geringer Bedeutung. Die Untersuchung lässt darauf schließen, dass die globale Bürgergesellschaft nicht als eine einzelne Einheit verstanden werden kann. Vielmehr werden die emanzipatorischen Inhalte und Bedeutungen der globalen Bürgergesellschaft durch die Konflikte und Interaktionen zwischen verschiedenen Gruppen geformt.

Resumen Este artículo explora el presunto potencial emancipatorio de una sociedad civil global en lo que respecta al activismo transnacional para promover el comercio justo ("fair trade"). Estudia el caso del activismo transnacional en Tratados Europeos de Libre Comercio, con ilustraciones de la campaña Stop EPAs y el activismo relacionado con la negociación de un Tratado de Asociación entre la Unión Europea y América Central. Observa la forma en que se expresan las ideas relacionadas con el comercio justo y el proceso de administración de la diversidad y la búsqueda de mensajes en común. Los activistas que trabajan en coaliciones abiertas norte-sur e ideológicamente diversas administraron las tensiones entre reforma y resistencia para los beneficios percibidos que derivar de una voz en crecimiento. A pesar que el activismo transnacional generó oportunidades de mayor debate y acción, promoviendo la inclusión de diversas voces, algunos puntos de vista aún se encuentran marginados en un contexto de búsqueda de compromisos. El análisis sugiere que la sociedad civil global no puede comprenderse como una sola entidad. Por el contrario, los contenidos y significados emancipadores de la sociedad civil global se están forjando a través de estos conflictos e interacciones entre los diversos grupos. 
Keywords Global civil society - Transnational activism · Free trade agreements

\section{Introduction}

The protests which challenged the World Trade Organisation (WTO) Ministerial Conference in 1999, known as the 'Battle of Seattle', were evidence of the growing mobilisation with regard to free trade and the discontentment associated with economic globalisation. A range of groups (trade unions, environmentalists, farmers, International Development-oriented Non-Governmental Organisations or Private Aid Agencies ${ }^{1}$ ), coordinated action across borders through networks and coalitions. How has this phenomenon been interpreted? Transnational activism has been interpreted as a sign of the emergence of a 'global civil society' (GCS) (Anheier et al. 2001; Kaldor 2003). Even those that doubt the existence of a GCS write that there is 'at least a trend toward new forms and new levels of transnational contention' (Tarrow 2005). Campaigns and actions are perceived as promoting positive values such as plurality, participation and democracy, very much needed in a context of patchy global governance. Some authors present activism as 'a counterforce to neoliberal globalisation' (e.g. Taylor and Naidoo 2004).

Though emancipatory and transformative potentials are attributed to GCS, little empirical and analytical research has been done to assess the extent to which these attributes are realised in practice, as pointed out by Taylor:

It is (...) this transformative dimension - the creation of a fairer, freer, and more just future in the present through prefigurative politics-that has not been captured in existing social scientific approaches. Not only must such developments be understood in their own terms, but also theory must be advanced to identify, understand, and advance the emancipatory potential of global civil society. (2002, p. 346)

In fact, most research has focused on describing its size and organisational forms (e.g. Salamon et al. 2003; 2004), joined by case studies of global campaigns (e.g. Edwards and Gaventa 2001). These campaigns are presented as influential in international politics. However, they do not provide empirical evidence of what this influence means in terms of realising the above-mentioned positive values particularly when it comes to economic policies.

Exceptions, which address this deficiency partially within the literature, are two empirical and interpretative works, namely Katz (2006) and Berry and Gabay (2009). Against the background of network structures in terms of inclusiveness, hierarchy and cohesion, Katz tests two views of GCS (one as co-opted by hegemonic capitalist and political elites, and one as the infrastructure from which a counter-hegemonic force could emerge). Yet, he focuses on the infrastructure of GCS, and not on the specific orientations to change and ethical choices in advocacy.

\footnotetext{
${ }^{1}$ Private Aid Agencies, are a sub-type of NGOs which undertake a wide range of humanitarian, development and advocacy activities, to a large extent making use of Official Development Assistance (ODA) funds of OECD-DAC committee members.
} 
His work concentrates on what networks do in terms of organisational dynamics, rather than on the content and type of social change aims. Secondly, Berry and Gabay contrast the ideal of a GCS with a practical case. They examine the case of Oxfam as a transnational political actor. They argue that Oxfam is portrayed using a liberal-cosmopolitan approach to GCS as representing a response or a challenge to globalisation at the global level, offering an alternative model of globalisation to the dominant neoliberal perspective. At the same time, however, their analysis of the self-perceptions of Oxfam's staff does, to a certain extent, question this understanding.

When it comes to activism in relation to economic policies, it remains unclear how transnational activism realises the emancipatory and transformative potentials expected of GCS. This is particularly necessary when the neoliberal policy paradigm is predominant but contested. Emancipation and transformation can be operationalised in different ways: for example, it can mean the extent to which individuals feel more empowered, capable and free. In this article, I only examine two aspects of the multiple ways in which citizens' activism can contribute to emancipation. Firstly, I look at the ideas present in actions and discourses related to what a better or ideal situation would be. I argue that this question is relevant because, in contrast to general perceptions, there is no normative consensus among activists in relation to free trade and development. What does good and fair trade mean if it were to promote development and societal well-being? Secondly, I explore the process of interactions among groups and how they reflect the values of plurality and inclusion. In other words, who defines what 'fair' means?

It cannot be taken for granted that there is one homogenous global justice movement with one definition of fair trade, and that the process of defining what 'fair' means is inclusive and participatory. Conceptualisations of transnational activism stem largely from activism promoting human rights and democratisation. In some policy areas, there seems to be a normative consensus on what is 'good'/ 'bad' (e.g. stopping the use of child soldiers, eliminating the use of landmines, stopping violations to civil and political rights). This normative consensus cannot be taken for granted in the area of economic policies (Nelson and Dorsey 2007). Campaigns that are rights-based draw their legitimacy from internationally agreed norms and from the growing body of International Human Rights Law. However, campaigns on trade and development are different. Although they also appeal to human rights standards, especially Economic, Social and Cultural Rights (ESCR), there is no agreement on how to make these rights a reality. These rights are limited by the 'principle of progressive realisation' and states are forced to guarantee them as much as their resources and capacities allow them.

Activism relating to trade and development taps into highly ideological policy approaches. Some economic paradigms appear to some to be the only alternative, while to others they are subject of contention. To some, neoliberal recipes can be identified as transformative and emancipatory, substantiated by scientific research. By contrast, others understand neoliberalism to be oppressing and unjust, and they contest the idea that 'there is no alternative'. Moreover, trade policy is a highly technical area and this makes it difficult for many people to participate meaningfully. Participation in trade policy is crucial as economic interests, profits, 
jobs and livelihoods are at stake. In this sense we can expect higher levels of discursive conflict to appear in transnational coalitions on trade and development policies.

This article aims to address this gap by exploring existing interpretations of fair trade among activists of diverse transnational coalitions and how they deal with these different approaches. By analysing specific transnational activist coalitions it is possible to shed light on what the emancipatory and transformative contents of GCS mean in practice. Transnational coalitions are a microcosm of the complex universe and realm that is global civil society (Magis 2010). By looking at both coalition activities and those organisations and individuals that take part in them, it is possible to assess the different understandings of what 'good' and 'fair' mean. This paper explores the idea that GCS is a site where these various meanings are present and various ideas are expressed and negotiated. It is a site of discursive struggles about what realising global justice would mean, rather than simply being a site via which pre-set positive global justice ideals are promoted or a consensus feasible. These discursive struggles take place in coalition meetings and during deliberations and wherever discourses are negotiated and shaped. Common messages and actions do not imply consensus or solved conflicts. Instead, they are only the tips of the iceberg. Under the water, as it were, there is an ongoing management of conflicts for the perceived benefit of increased impact of joint actions.

The transnational coalitions that emerged to challenge European free trade agreements (FTAs) have been chosen for analysis for two main reasons. First, activists responded to the increase in the number of negotiations. The impasse reached during the Doha Development Round negotiations and the increase in negotiations on bilateral and bi-regional FTAs (UNCTAD 2007) led to increased activity in response to these negotiations in recent years. The EU has signed 33 FTAs and is presently negotiating $23 .^{2}$ Secondly, the challenges facing the EU's approach reflect, in particular, the ideological diversity within coalitions. The EU promotes free trade and explicitly depicts negotiations as pro-development (Faber and Orbie 2008). Furthermore, the fact that the EU has been negotiating FTAs with developing countries and regions makes the negotiations highly asymmetric in terms of economic, political and technical power. As a result, their 'fairness' was a point of contention. The EU's approach is based on the idea that regions need to integrate into the world economy to benefit from increased market opportunities, increased investments and economic growth and thereby help to achieve poverty reduction (European Union 2006). The aim was to improve market access opportunities and advance an ambitious liberalisation agenda. This agenda includes areas such as services, Intellectual Property Rights and public procurement markets which had become bogged down in multilateral negotiations. These areas have been contested to a large extent by, for example, human rights and indigenous

\footnotetext{
${ }^{2}$ Updated to 5 February 2010 at EU DG-Trade Website http://trade.ec.europa.eu. This information includes FTAs as notified to WTO under GATT article XXIV. The Association Agreement with Central America was officially signed last May 2010 and not included yet in DG-Trade list, but included as signed here.
} 
movements. The transnational coalitions formed to challenge the EU's approach to FTAs appear to provide a voice for a diversity of groups such as farmers, associations of enterprises, private aid agencies and human rights organisations, both in the 'North' and in the 'South'.

For practical reasons, examples and illustrations presented for this paper are related mainly to two sets of negotiations. These are the Economic Partnership Agreements (EPAs) negotiated with 76 African Caribbean and Pacific (ACP) countries signatories of the Cotonou Agreement and the Association Agreements Negotiations with Central America (known in Spanish as the AdAs, short for 'Acuerdos de Asociación').

This article is structured as follows. A discussion of conceptualisations of global civil society and transnational activism are followed by methodological details. After that, coalitions and networks active in the chosen case studies are mapped and described in terms of the groups that are included and their basic characteristics. This is followed by an analysis of the different interpretations of the desirability of free/fair trade and an examination of the way coalitions have dealt with these different interpretations. Finally, the conclusions summarise the research findings and propose some areas for future exploration.

\section{Global Civil Society and Its Alleged Emancipatory Potentials}

This section discusses conceptualisations of GCS. Though important contributions have been made, current understandings have certain limitations. I propose a more nuanced conceptualisation: GCS is conceptualised here as both an arena-where forceful discursive struggles take place-and a forum, where more deliberative forms of dialogue take place. It is in this space that the normative contents of world politics are shaped. Empirically this space is created through the interactions between different groups which collaborate and form specific transnational activist coalitions. The section ends with a discussion of the new forms of transnational activism.

\section{Interpretations of Global Civil Society}

GCS has become a common concept when it comes to understanding contemporary global politics. However, in the past decade its analytical power and normative claims and have been subject of debate. As 'civil society' became part of mainstream discourses, so did 'global civil society', suffering as it did from 'concept inflation' (Munck 2006; Taylor 2002). Initial descriptive attempts have equated it to the increase in numbers and types of organisations that are active transnationally (Salamon et al. 2003). It has also been understood as a 'reality in the making' (Anheier et al. 2001) and as 'an ideal type' (Keane 2003). Liberal/ cosmopolitan and pluralists consider international civil society actors to be valuedriven and as promoting a human rights agenda and as helping to improve accountability in institutions of global governance (e.g. Kaldor 2003; Florini 2000; Scholte 2005). 
Others argue that pluralists take a shared normative agenda too much for granted when, in reality, it is a Northern Euro-centric and universalistic project which subsumes particularisms (Anderson and Rieff 2005) and that GCS can also be a place of 'incivility' (Colas 2004). Those that follow the Gramscian idea of civil society as a space of struggle for hegemony propounded the idea of GCS as a means of building a 'globalisation from below' to counter the dominant 'globalisation from above' (Falk 1999; Lipschutz 1992). Those allegedly value-driven actors are in fact 'implementers of a neoliberal agenda' and therefore of a certain interpretation of values. GCS is therefore a space that has to be re-conquered in order to realise real alternatives to market-oriented development models (e.g. Manji and O'Coill 2002; Waterman 2005), or 'little D' alternatives (Bebbington et al. 2008). Those perspectives that signify GCS either as promoting hegemony or forging resistance to it share a normative perspective: GCS is a space to build what is 'good' for our common future.

Nevertheless, debates have limited the analysis to a dichotomy, and have failed to grasp the more complex dynamics involved in the creation of a variety of alternatives. Katz's analysis of GCS network infrastructures (2006) suggests that both Gramscian-inspired models (hegemonic and counter-hegemonic) could be possible. On the one hand, GCS is structured hierarchically and reinforces inequalities. On the other hand, there is an increasing number of coalitions of subaltern groups, dense and more egalitarian interactions and inclusive structures. Katz argues that GCS is in a transitional phase in a search for more hopeful futures. The question is what do these hopeful futures mean for the diversity of groups and their related interests?

\section{Global Civil Society as an Arena and a Forum}

Magis's (2010) study explores how groups deal with diversity and propose the idea of 'convergence' which would allow these groups to act collectively. Magis defines GCS as 'an ideal type to describe and explain the endeavours of civil society groups collaborating internationally to promote the public good' (Magis 2010). However, this definition is problematic as it assumes that groups tend to collaborate, rather than be at conflict, with each other. Bond (2006) argues that the need to reach common positions often leads to watered-down and less effective messages. Secondly, Magis' definition proposes that the ultimate purpose of GCS is to promote the public good, although this public good is left undefined. By contrast, Amoore and Langley put more emphasis on the "contested nature of GCS as a platform for diverse political struggles' and argue that 'It is the perpetual struggle to define the terms of the movements that, in large part, constitutes the politics of GCS' (2004, p. 108).

I regard global civil society as both an arena where actors struggle about meanings and resources and a forum for deliberation. ${ }^{3}$ It is a site where political

\footnotetext{
3 The word 'arena' refers to a space for sports and competition and was first used to describe Roman public spaces where gladiators and other spectacles were staged. This word is therefore associated with fighting and struggle, involving force, skill and luck and performers and a passionate crowd. Nowadays, groups fight to advance their aims using all the resources at their disposal. The word forum also refers to a public space, but in Roman times it was used for business and discussions. The connotations of the word are related to exchange of argumentations, and therefore a place for reasons and ideas.
} 
discursive struggles take place, that is, discussions about meanings of what a 'good' society should look like. This definition builds on Dryzek's idea that ' $[\mathrm{M}]$ any if not most of the main axes of conflict in today's world can be interpreted in terms of contending discourses'. (Dryzek 2006, vi). ${ }^{4}$ If discursive contestation in international public spheres plays a central role, the importance of civil society should not be mainly related to its participation in formal decision-making, but rather to its contributions to deliberations on, and the formulation of, policy proposals. In this sense GCS is a realm in which this deliberation takes place and where forms of transnational discursive democracy can be observed. The emancipatory potentials of GCS can then be realised in terms of the quality of deliberation that it allows and promotes. If various perspectives and visions can be expressed, interactions and dialogue lead to better proposals. GCS can be a kind of site for problem-solving and for the transformation of conflicts in which state and market logics may remain attached to their sectorial interests. I argue that crucial interactions happen within, and through, transnational activist coalitions.

\section{Transnational Activism}

The way that transnational coalitions have dealt with diversity has been the focus of recent literature on transnational activism, although the emphasis has mostly been on incentives for collaboration. Diversity in terms of cultures, thematic focus, political orientations and approaches to social change have been addressed. Usually, different approaches to activism have been referred to as 'insider' and 'outsider' approaches. 'Insider' approaches tend to favour working with formal institutions or governments, thereby making use of formal or 'invited spaces' (Gaventa 2006) and favouring cooperation. 'Outsider' approaches, on the other hand, are often more critical and create their own spaces. Their access to formal spaces is limited, denied or activists themselves choose "not to make use of those institutionalised channels of engagement or invited spaces' (Newell and Tussie 2006, p. 12). Della Porta and Tarrow (2005) indicate that there is more hybridity in activists' strategies and tactics.

Diversity is also reflected in multiple and innovative ways of organising and mobilising, ranging from loose networks of information sharing to formalised international federations of organisations. These organisational forms allow for the coexistence of 'multiple identities' (Della Porta and Tarrow 2005). Magis (2010) goes a step further and argues that organisations find common ground to act collectively so as to effectuate change despite diversity, proposing the concept of convergence: 'The challenge, they [interviewed] stated, is not to resolve or homogenise diversity, but rather to conserve diversity and to discover Convergence across the difference to enable effective voice.' Diversity is presented as a resource which can be harnessed for success. However, the emphasis on compromises and

\footnotetext{
${ }^{4}$ Dryzek interprets discourse as 'a shared set of concepts, categories, and ideas that provides its adherents with a framework for making sense of situations, embodying judgments, assumptions, capabilities, dispositions, and intentions.' (2006, p. 1).
} 
commonalities has overshadowed the fact that coalitions manage conflicts and coexist with contradictions, rather than resolve them.

A different yet related study is the one which analyses the involvement of European NGOs in trade policy by Dür and De Bièvre (2007). The authors differentiate two types of organisations. On the one hand, those of concentrated interests, that is organisations which have properly defined their interests in economic terms, such as associations of enterprises and trade unions and, on the other hand, those of 'diffuse' interests, that is, organisations that promote general public interests (Beyers 2004). In their study, European NGOs would be organisations of diffuse interests. This differentiation is useful. However, their study does not consider the effects of joint actions and coalitions. It only assesses the influence of these different types separately.

\section{Methodological Considerations}

Data gathering consisted of documentation, observations of events and internal meetings and interviews with key actors, in the period between February 2008 and December 2009. During the first phase, I observed events and activities of networks of organisations working on trade and development. These were the civil society activities at UNCTAD Conference in Accra 17-23 April 2008, a public hearing on European FTAs at the European Parliament on 9 April 2008, the CIVICUS Assembly in June 2008 and the International Encounter of Social Movements and NGOs engaged in negotiations between the EU and Latin America, organised by ALOP, CIFCA, Oxfam International and others in Brussels, on 10 July 2008.

A total of 101 interviews were conducted with main actors. ${ }^{5}$ However, the emphasis on analysis for this paper centres round the perceptions of activists. Interviews and observations were conducted in Accra (Ghana), Dakar (Senegal), Abuja (Nigeria), Tegucigalpa (Honduras), Brussels (Belgium), Stockholm (Sweden), Madrid (Spain) and The Hague (the Netherlands).

Data was analysed in two phases. First, a content analysis was carried out of collected documents, interviews and observation notes in order to identify the main themes, nodes of contention and legitimation strategies. Secondly, discourse analysis implied the identification of different meanings attributed to concepts.

\footnotetext{
${ }^{5}$ In the case of EPAs: European Commission and EU Member states (16); ECOWAS, Senegal and Nigeria officials (5), EU Parliamentarians Assistants (2); European Private Aid Agencies (16); West African NGOs (6); Trade unions in West Africa (4), Farmers Association in West Africa (1); Private sector in West Africa (2); Media and researchers in Europe (4), Media and researchers in West Africa (3). For the case of Adas: European Commission (4), European Parliament (1), Government of Costa Rica (1), Government of Nicaragua (1), Government of Guatemala (1), Central American Parliamentarians (2), Trade expert from Costa Rica (1), Trade expert from the Netherlands (1), farmer organisations from Honduras (1), Association of Enterprises from Honduras (1), Central American organisations (8) European NGOs (17), Trade unions in Central America (2), Trade Unions in Europe (1).
} 
Discourses are understood as being a set of concepts and categories that help actors make sense of reality (Dryzek 2006).

\section{Diversity in Transnational Coalitions and Networks}

This section maps the main coalitions and networks active in the chosen case studies and describes their organisational composition and basic characteristics. A diversity in the type of organisations engaged around European FTAS could be observed. There were five main active groups of organisations: (1) Associations of small and medium size producers and farmers, for example ROPPA (Network of small scale farmers of West Africa or local and regional associations affiliated to La Via Campesina. (2) Associations of businesses and industries, for example MAN (Manufactures association of Nigeria), NANTS (National Association of Traders of Nigeria). (3) Trade unions like ITUC (International Trade Union Confederation) and their regional branches such as ETUC (European Trade Union Confederation), and local federations like GTUC (Ghana Trade Union Confederation). (4) Private Aid Agencies, notably Oxfam International and the federation's members, Action Aid, Christian Aid, ICCO, Both Ends and European networks such as CONCORD, APRODEV, CIDSE, ALOP and CIFCA. (5) Association of citizens with a specific thematic focus (environment, women) like Friends of the Earth International. (6) Research and advocacy NGOs/think-tanks such as ECDPM, Funde or Iniciativa CID.

The first three types are organisations of concentrated interests, more or less directly for-profit organisations whose livelihoods were at stake. The last three types of organisations are of 'diffuse' interests, predominantly private aid agencies. One of the main and distinct characteristics of observed transnational activists coalitions is that they were formed by both for-profit organisations, though indirectly via their associations and federations, and non-profit ones. This makes these transnational coalitions different from those observed in previous studies, which focus mostly on civil and political rights as well as other noneconomic policy areas.

These organisations engaged in different levels of collaboration which overlapped and coexisted. Some participated in open and less formalised networks, only exchanging information and communicating with each other. Others formed functional networks that are open coalitions with eventual coordinated actions and collaboration. Thirdly, a few formal coalitions were created which planned and implemented actions under one single message. Some networks were created to follow the Cotonou Agreement and some existed in relation to the World Social Forum. Pre-existing national and local civil society platforms such as the Senegalese Social Forum, the Nigeria Trade Initiative, PASCIB (Benin) and CHAAC (Honduras) joined regional, continental and international networks and platforms. At regional level in West Africa, the West African Civil Society Platform on the Cotonou Agreement, facilitated by ENDA, took up the leading role, supported and in cooperation with the Africa Trade Network, coordinated by TWNAfrica. In the Americas, the Hemispheric Social Alliance was very active and led to, 
among other things, the creation of a bi-regional network Latin America-Europe called 'Enlazando Alternativas' (Linking alternatives). In Europe, organisations gathered around CONCORD, the European Trade Network, the Seattle to Brussels Network ${ }^{6}$ and CIFCA.

The webs of coalitions and networks can seem confusing, yet it is a few key individuals and organisations that play the role of connectors. In this sense, individuals within organisations based in Brussels, such as the Belgian Federation 11.11.11. and CIFCA, played a crucial role in articulating networks and in sharing information. Actions were organised so that different organisations would take up specific roles at their level of operation: awareness-raising at local level, advocacy at national and regional levels with regard to regional institutions and coordination at international levels. Individual organisations and coalitions started to use existing channels of communications and networks to exchange and discuss possible actions. For example, the World Social Forum, and its regional and national forums and trade-related meetings served as a space for encounter and coordination. The Civil Society Forum organised parallel to UNCTAD in 2008 was a good example of such a meeting point. Connections between organisations and movements had already been built during existing campaigns such as the Make Fair Trade Campaign or 'Our World is not for Sale'. In that sense, there was a strong continuity between those following WTO negotiations, EU policies, the Cotonou Agreement and the groups that finally mobilised around new FTAs.

In 2004, a bi-regional (STOP) EPA Coalition emerged. Though the coalition was large and open in its organisational form, there was a 'core' coalition formed by key European and ACP groups, and a wider coalition including various networks and spontaneous movements. At the core there were two Research and Advocacy NGOs from West Africa, ENDA and TWN-Africa, an association of traders based in Abuja which facilitated and European private aid agencies in Europe. These organisations played key roles in articulating the multi-regional network via their international work and connections and in providing expertise. European private aid agencies also provided funding. A wider set of groups converged on key days of action such as the Stop EPAs days in September 2006, 2007 and 2008.

Although there were several other bi-regional networks which monitored FTAs in other countries and regions, they did not formalise as the STOP EPAs coalition. For example, in the case of negotiations with Central America, CIFCA, APRODEV, CIDSE and Grupo Sur worked closely with partners and allies in other regions but did not formalise a campaign as they did not agree on a common message.

Given the composition and organisational forms that emerged, three main characteristics of transnational activism could be observed. First, coalitions were composed of both 'concentrated' and 'diffused' interests' organisations, and complementariness was perceived as an incentive for collaboration. Small-scale farmers, local industries and trade unions mostly in West Africa and Central America provided important resources to the coalitions. One of these was

\footnotetext{
${ }^{6}$ Seattle to Brussels Network. The network is called 'Seattle to Brussels Network-Taking Action Against Corporate Globalisation'. The S2B network is the European part of the global 'Our World Is Not For Sale' network (OWINFS).The S2B network includes development, environment, human rights, women and farmers organisations, trade unions, social movements as well as research institutes.
} 
legitimacy. Their livelihoods were at stake so they had to be heard, and they updated information on the potential negative impacts of the agreements on their sectors.

Secondly, coalitions were open and, given the number and type of groups that were involved, we can assume that they allowed ambiguity and a diversity of approaches to social change. Coalitions combined actions of 'insiders' and 'outsiders'. Some members focused on public and mass mobilisation actions like petitions, demonstrations, and the placement of banners in the public space. Others preferred direct meetings with policymakers (lobbying) and participation in invited spaces based on research and policy papers. To some extent there was a certain distribution of roles. This confirms the trends observed by Della Porta and Tarrow (2005) in terms of being coalitions of multiple identities.

Thirdly, being North-South negotiations with development aims, organisations needed partners in the other region for the purposes of information exchange and the organisation of actions. Consequently, these transnational coalitions were composed of groups in the 'North' and in the 'South'.

\section{Interpretations of Fair Trade}

This section provides an analysis of the different interpretations of fair trade present in the transnational coalitions observed. These interpretations are rooted in the debates on free trade which have a long history. The main issue for discussion is that market liberalism ${ }^{7}$ may lead to economic growth of some but not all. In more recent decades, it has been argued that free trade may not necessarily be fair as it may not lead to pro-poor development. Another argument is that global capitalism is ecologically unsustainable. One idea is prominent, namely that free trade may increase wealth for many, but that inequality may also worsen the conditions of those vulnerable groups that cannot harness the opportunities created by enlarged markets. However, this does not contradict trade theory. The fact that there may be winners and losers is acknowledged, not only in academic studies but also by policymakers. The advantage of free trade and the reason why it is fair in the eyes of some is that, overall, most stand to gain. It is the role of social policies to address often inevitable and unexpected adjustment costs of global integration.

In relation to different ways of representing economic reality, several discourses exist on economic globalisation. These discourses draw from economic theories and models and circulate through policy paradigms as frameworks which are intended to guide policymaking. A schematic categorisation is proposed based on Desai and Said (2003, p. 66) and adapted for the purpose of this study. In brief, they propose five main policy paradigms in relation to levels and kinds of desired global market

\footnotetext{
7 In a simplified manner, the predominant neoliberal policy paradigm sees the relation between trade and development as follows: integration into a global market $\Rightarrow$ more trade $\Rightarrow$ more opportunities $\Rightarrow$ more economic growth $\Rightarrow$ more development (given private property, legal security, investment) $\Rightarrow$ poverty reduction $=$ free trade is the best for the poor. This policy paradigm has been supported by economists who argue that, on average, living conditions have improved as a result of trade liberalisation polices, based on certain conditions. A few have contested these opinions, arguing that although growth may have increased overall, there is evidence of rising inequality (Wade 2010).
} 
integration. These are 'Supporters' of global market integration, 'Regressives' (global trade is 'good if on our terms'), 'Reformers' (trade can and must be made more equitable, WTO could be reformed and re-distribute policies should be put in place), 'Alternatives' (it is the State and corporations that are the problem) and 'Isolationists' (the state should be re-empowered and the WTO abolished). These five groupings coexist with a variety of discourses such as the Human Rights discourse, the sustainable development discourse, the industrialist discourse, and so forth. (Dryzek 2006, p. 2). Rather than fixed categories, they represent main tendencies which often show 'contaminations' from discourses typical of other paradigms.

These approaches can be found in the transnational coalitions that challenge European FTAs, made up mostly of 'reformers' and 'isolationists' and, to a lesser extent, 'alternatives'. As illustrated in extract 1, European private aid agencies adopted a reformers' approach.

\section{Extract 1: Manual on EU FTAs by Christian Aid, Oxfam and Action Aid (2008)}

Trade agreements can be important. For neighbouring countries at similar levels of development, they can create larger, more effective and more attractive markets. Economic and political ties can be mutually reinforcing. However, when FTAs occur between countries at vastly different levels of economic development, they often serve to undermine rather than support the development process. (My emphasis)

Together with supporters, reformers accepted that trade can bring economic growth and therefore development. The problem was the pace and scope of liberalisation, the fate of vulnerable groups and the considerations given to the fact that two countries or regions may have different starting points. Unfair trade was therefore trade which did not recognise asymmetries and structural barriers to taking advantage of new opportunities. The conclusion was that it was necessary to reform trade rules and policies so as to address the negative effects of liberalisation. The basic assumptions of liberal trade theory were not challenged.

This reformist approach is present in the EPAs campaign where the main discourse was that the scope and pace of trade liberalisation had to be brought into question if development dimensions were to remain central in the agreements. EPAs are presented as equivalents of unrestricted trade liberalisation, expressed in a negative manner. EPAs are presented as a bad option through the use of words with a negative connotation like 'devastating', 'damaging', 'major losses'. Though EPAs are presented as a bad option, the texts do share basic assumptions with the EC propositional assumptions: 'trade can bring benefits', 'it can be a powerful tool', 'a healthy economy is a competitive one'. Texts mostly challenged the asymmetries in power. They also contested the fact that conditions are not such so that ACP, presented as poor and dependent, could compete with the EU, presented as rich and ambitious. Though basic liberal assumptions were retained, it was the pace and scope of liberalisation which were contested, as well as the support for these economies to enable them to deal with supply-side constraints, reforms and 
adjustment costs. The role of the state, through countries' socio-economic policies in general, supported by external aid, are important to address these constraints and costs. Most texts reflect an overall reformist approach which we can place in the social/mixed economy paradigm. In this line of thought, the scope of WTOcompatible policy alternatives was expanded. Important contributions in this direction were made by ENDA and ECDPM that issued policy papers and analysis from technical-legal perspectives. One useful example is the 2006 ECDPM report 'Alternative (to) EPAs, Possible scenarios for the future ACP trade relations with the EU', which showed WTO compatible options (EPA Coalition 2006).

Other groups adopted a more isolationist approach. For them, changing the rules was not enough: it was the system which needed to be changed. Trade liberalisation was understood to be a strategy to advance the interests of the powerful and as a continuation of colonialism and imperialism. Therefore, FTAs should be resisted as they are channels that deepen neoliberal globalisation. Freedom is the freedom of people to decide about their future. This is the freedom that should come before the freedoms of markets and of investors. This second approach is illustrated in extracts 2 and 3:

\section{Extract 2: Bilaterals, Biothai and Grain (2008)}

The origins of today's FTA mania lie in a long history of colonial exploitation, capitalism and imperialism - just as many of today's people's movements against FTAs trace their own histories to previous generations of anti-colonial, anti-imperialist resistance and struggles for self-determination. (...) FTAs are today a tool of choice to lock in and expand the discredited, socially and ecologically destructive model imposed on much of the world in the name of 'development' by the World Bank, IMF and regional financial institutions. (My emphasis)

\section{Extract 3: Enlazando Alternativas/People's Summit Statement Madrid, May} 2010

We energetically reject Free Trade Agreements, Association Agreements and bilateral investment treaties - or Treaties of Investments Promotion and Protection - agreed among some Latin American and European countries, which have been negotiated on the backs of and against the interests of our peoples. (...) 17. We make the struggles and demands of indigenous peoples ours, and for the 'buen vivir' (good living), the creation of pluri-national states and the recognition and defence of the rights of our mother earth, which contribute to the necessity of developing consumption and production models that are more sustainable, responsible and fair. (My emphasis and translation from Spanish)

In extract 1 organisations question the development potentials of free trade but do not challenge the development model (understood as market liberalism) per se. The model can be improved. For example, rules need to change and opportunities need 
to be created for poor people to benefit from access to markets. Rules are needed in order to address asymmetries adequately. In extract 2 and 3 the model of development is questioned. Not only does it have negative social and economic consequences, it is also 'ecologically destructive'. A new narrative appears in extract 3: that of looking for 'good living'. However, what this means is not fully spelled out, as was also acknowledged during a meeting of activists in Madrid. ${ }^{8}$

These reformers and isolationist approaches are accompanied by strong references to human rights frameworks. In the case of activism on AdAs, a rights-based approach is much more explicit and central, as illustrated in extract 4 which is a letter signed by European networks. The right to development is mentioned in order to legitimise the demands made to policymakers.

\section{Extract 4: Open Letter to Commissioner Ashton (CIFCA 2009)}

In this respect, it must be warned that deregulation of State actions to favour private interests - related to financial speculation and major enterprises - has limitations in these association agreements seeking to favour the free trade of goods, services, and capital, over the responsibility of governments in guaranteeing the full respect of human rights, the environment, and the right to development for their own peoples.

The negotiations for the Association Agreement with Central America affect rather than promote - the right to development: We have insisted that the Singapore Issues (government procurement, competition, and investment) be excluded from the negotiations. These issues reduce the autonomy of governments in defining their own development models as well as the sovereignty over their natural resources, which in turn limits the requirements of investment performance, exposes national companies to unfair competition from multinationals, and provides the latter with more advantages, rights and enforcement mechanisms than the very protection of human rights. (My emphasis)

Figures 1 and 2 illustrate the different approaches to free trade (supporting global integration and the rejection of integration/alternatives) for the two case studies analysed in more depth. They also illustrate the different organisational approaches to activism ('insiders'/using formal spaces or 'outsiders', creating or using nonformal spaces). We have observed that many organisations use both 'insider' and 'outsider' strategies. It is important to highlight that though organisations are located here in a certain 'position' for illustration purposes, in reality the picture is more dynamic.

The reformist line contrasted with that of texts in which a more 'isolationist' approach is adopted, usually declarations or 'civil society statements' (e.g. EPAs Coalition 2 2007a, b). While European private aid agencies had a more reformist approach, some of their main partners in Africa, like some groups within the Africa Trade Network, discursively opposed the negotiation of FTAs altogether. For

\footnotetext{
$\overline{8}$ Observations in Madrid, March 2010.
} 


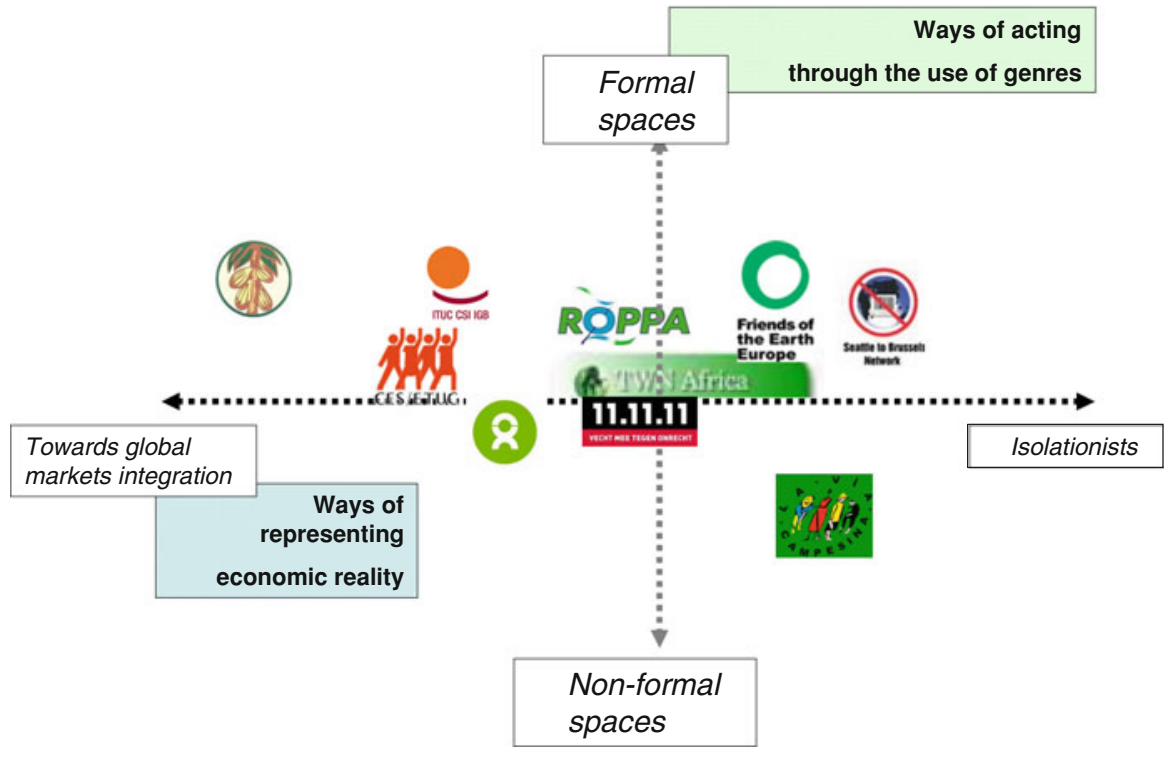

Fig. 1 Actions and ideas-EPAs case

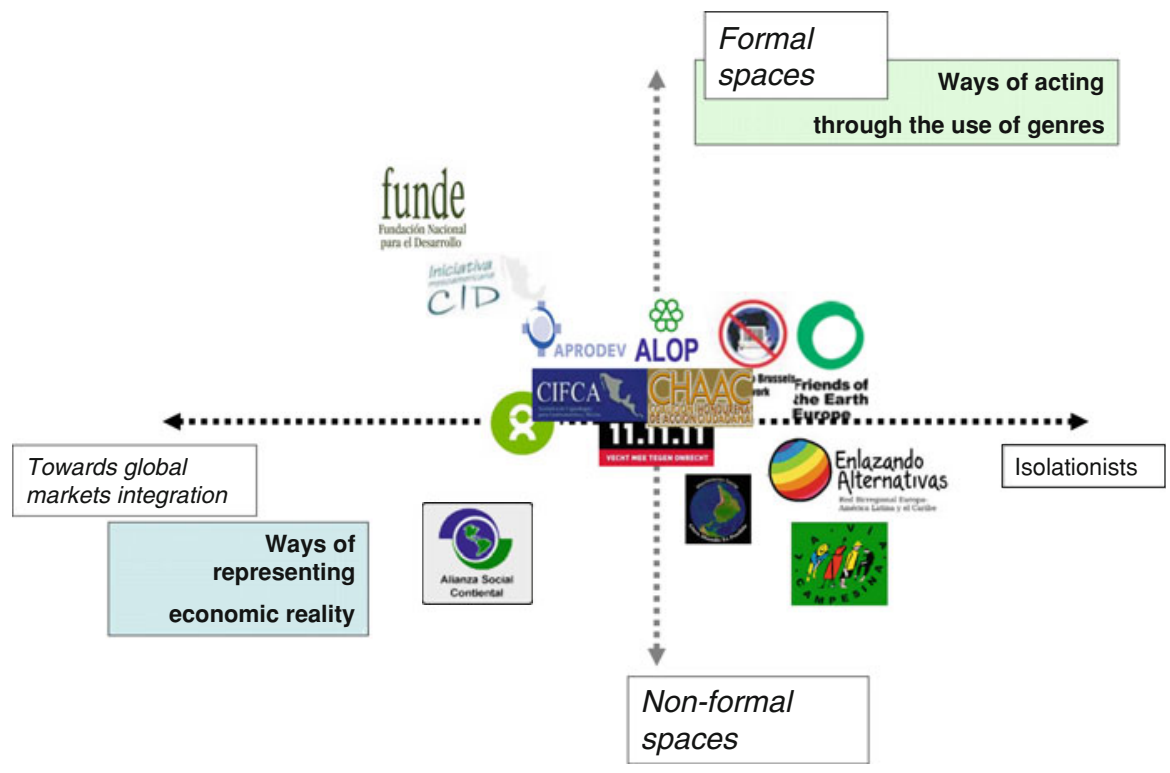

Fig. 2 Organisations and networks-AdAs case

example, they state their positions on the Declaration of their 9th Annual Meeting (African Trade Network 2006). In these declarations there is a categorical rejection of trade liberalisation. In the case of EPAs, it appears to be 'a lesser evil' to have 
WTO-compatible alternatives in the event of overall opposition to the underlying principles of the multilateral trade system as structured through the WTO.

\section{Working with Diversity in Conflictive Symbiosis}

This section examines the way coalitions have dealt with different interpretations of fair trade and approaches to activism. During observations of activists meetings and actions, I noticed that there is both respect for diversity and a desire to persuade others to change their interpretations. Different interpretations coexisted, and sometimes this situation resulted in conflicts.

\section{Conflictive Symbiosis}

Activists found incentives to collaborate transnationally. They needed allies in the 'other' negotiating region as they could facilitate access to strategic information and analysis from all the countries and regions involved, help address the challenge of scarce human and financial resources and enhance the overall legitimacy and credibility of the campaign. Considerable resources were allocated for the EPAs campaign, although this was not the case for actions in Central America which is not a priority region for many donors and private aid agencies. Furthermore, financial constrains hindered the organisation of strategic meetings and activities in Central America, while the availability of funds may have encouraged organisations to work together more in the case of EPAs.

In both cases, generally different points of view were exchanged and respected. According to an activist from Ghana 'One of the great achievements of the EPA campaign was the respectful cooperation that was generated between and amongst participants in the campaign, all over Africa.' Positive views such as this indicate to us that the process of coalition building and joint action has respected plurality, and therefore realises the attributed positive values of GCS in practice. Others indicated that there were often conflicts and that they needed to reach compromises. 'When you are clear about your positions, it is easier to be flexible about the tactics' explained an activist which coordinated a regional African network.

The need for negotiation and compromise is a positive indication of respect for plurality and respect for diversity. However, others had a different view and explained that there is lack of trust and less cooperative relations. This was noted in both cases, but there was one illustrative example from the negotiations with Central America: a representative of a farmers' organisation ${ }^{9}$ from Honduras explained:

We had a clear 'no' position. They [referring to European groups] lack this [clear positions], sometimes they say yes, sometimes they say no. (...) In some cases this is counter-productive as they influence social organisations with watered-down thinking. We do not believe what they say. If the discourse was in order, the strategies would be easier to accept.

\footnotetext{
9 Interview in Tegucigalpa, Honduras, April 2009.
} 
It seems as if groups work together in a sort of conflictive symbiosis to manage diversity. Different groups state that they need each other. This is not only expressed out of politeness and in my observations I noted the need and use of strategic information exchange and resources. Some groups needed the legitimacy and operational capacities of partners from the South, while others needed to be included in information sharing networks that swap strategic information from other regions. Still others simply needed access to financial resources. Interviewees working for national organisations explained that by participating in regional and international networks they had access to resources and information that would otherwise have been difficult to access. For example, a leader of an association of enterprises from West Africa explained ${ }^{10}$ that they 'accessed research that they would otherwise not have been able to produce' and that 'International organisations have been very dynamic and, at the same time, they have supported and challenged the negotiation process. They have been very vocal. They brought credibility to our positions'. The interviewee also mentioned how important it was to get strong statements from members of the European parliament.

Bi-regional negotiations created the need for a bi-regional collaboration and coordination. As a leader of a regional network from Ghana explained ${ }^{11}$ :

Having this relationship with European groups reinforced our positions and also reinforced our legitimacy. Because they are in Europe, they can speak to their governments to put pressure on European and African governments and come up with common positions. (...) We have analytical capacity, we all share these things in pursue of agreed political ...But when the actual intervention comes, particularly in the South, we should take the lead. They take the lead in the North. We should create platforms in both places where we can (...). The way the work is organised starting from the assumption that the weight of the power in the EPAs is of course in the North and therefore they [Northern partners] have a very important role.

The coalition members benefit from diversity but several challenges had to be overcome. Firstly, there were various understandings of the negotiations within each region. Secondly, there were tensions relating to roles and representation, still latent from the history of relations and nature of 'partnerships', especially between Northern private aid agencies and their counterparts in the South (Elbers and Schulpen 2010). For some the lack of common agendas was counterproductive. For others, coexisting with the conflicts was in itself emancipatory, as it led to more reflection.

A staff member of a European private aid agency based in Central America ${ }^{12}$ explained that they had observed distances and conflicts among organisations which had been present since the mobilisations against CAFTA. This supports the findings of the study by Spalding (2007). They believed they (private aid agencies) had a facilitating role and were trying to achieve a common agenda. As he explained,

\footnotetext{
${ }^{10}$ Interview in Abuja, Nigeria, May 2009.

11 Interview in Accra, Ghana, April 2008.

12 Interview in Tegucigalpa, Honduras, April 2009.
} 
"We tried to bring the different positions together. We played the role of a "chewing gum' because before, those sitting around the table now could not even meet." Two interviewees, a representative of a European network ${ }^{13}$ and a staff member of a Latin American network of Development NGOs ${ }^{14}$ noted that, despite the conflicts, one of the main outcomes of their efforts was that they improved dialogue about and respect for different perspectives among organisations. In sum we can conclude that, rather than compact coalitions, there were synergies among organisations, an exchange of information and attempts to avoid overlaps in the timing of events. There were more channels of dialogue, yet, the pre-existing conflicts remained. There was an ongoing discursive struggle which was managed on an ongoing basis. Ideological differences could not be easily overcome, however, the need to cooperate sustained their interactions.

\section{Discursive Interactions While Searching for a Common Strategy}

We will now examine in more detail the process of mobilisation and the search for a common agenda and strategy. The case of the EPAs campaign is a good illustration of how different voices and views on trade liberalisation appear in texts and change over time. It is useful to analyse the first text signed jointly by both European and ACP groups at the beginning of the campaign (EPA Coalition 2004). The aim of this paper is to respond to and clarify the reasons for opposing EPAs. At the beginning of the campaign, some activists proposed a STOP EPAs campaign, arguing that all negotiations should be stopped, while others did not oppose the negotiations altogether but wanted to influence their contents. This is why a compromise was reached and the final title was 'Stop EPAs in their current form', as proposed by the EU implying an ambitious liberalisation agenda. This meant the adoption of a rather reformist stand. We will now examine how the argumentation is built in the text.

The text shows high intertextuality: it contains 18 direct quotes and 42 references to non-campaign issued documents. However, it is striking that all of these quotes and references are related to official documents or persons with high academic credentials. There are no quotes by either coalition members or related civil society groups that would be affected by the EPAs. Despite it being a position paper, there are no references to 'we' or 'civil society'. The legitimisation strategy of these arguments is built not only on a civil society 'unreasonable' claims, but mostly on references to many 'official' voices that support these claims. In this sense, legitimisation is built on authorisation by making references to authorities (most notably ACP officials, parliamentarians) and on rationalisation, appealing to existing agreed rules in the frame of the WTO and UN, and references to the MDGs. The whole text is intended to challenge the EU approach to the EPAs by presenting five myths that the EU wants to keep alive. Arguments for depicting the EU's approach as a myth are built on several 'voices': those of ACP and the same EU as expressed in the Cotonou Agreement, a selection of ACP Presidents and Ministers,

13 Interview in Brussels, Belgium, March 2009.

14 Observed at UNCTAD conference 2008 and at a hearing at the European Parliament on 9 April 2008. 
EU Member States in the form of Prime Minister and Official Commissions statements, UN agencies, WTO provisions, East African parliamentarians and an economist from the Financial Times. It is not what 'civil society' thinks, it is what they - as governments - and their institutions have agreed. The message of the text can be summarised as 'you are contradicting yourselves', 'stick to your commitments' and 'those who you claim back, actually are not doing so'. The signatories appear neutral and are portrayed as two 'them' vs. 'them' situations. The EPAs are challenging credible economists and international institutions and rules and it is the EU vs. ACP governments. This contrasts with later texts which represent the period of consolidation of the campaign, in which more and different civil society opinions appear in a more assertive manner and, for example, include quotes by representatives of farmers, workers and women.

The discussions over agreeing on one main message clearly showed that there were different understandings and approaches to free trade. Though there were different positions, there were also common concerns and needs and therefore incentives for cooperation. The slogan 'Stop EPAs in its current form' was adopted. In practice, however, some used the short version while others emphasised that they wanted reforms rather than stopping the negotiations. Again it seems as if the coalition worked in a conflictive symbiosis, together but apart.

In the case of negotiations with Central America, the bi-regional networks could not agree on a common message. In almost every planning/evaluation meeting that I observed, some groups proposed launching a more determined 'No to Adas' slogan. Often in meetings, however, other groups - especially some private aid agenciesbelieved that such a slogan would halt dialogue with governments. They argued that they preferred to have fluid communication with policymakers as they were their partners and donors. Organisations adopted more or less reformist/isolationist strategies depending on the occasion, partners and changing political context. Discussions within coalitions had to deal with time limits and other constraints, such as the pressure to decide timely actions. This left almost no room to explore coalition members' underlying theories of change. As a result, what was really meant by 'fairer' trade and underpinnings of trade theories was not made explicit nor discussed about.

It is worth noting that the level of polarisation in terms of ideological positions was higher in the case of Central America. In this region, there was a recent history of social mobilisation in the context of the CAFTA and ALCA negotiations. Positions for or against free trade had been further pushed to the extremes as evidenced by the Referendum of October 2007 in Costa Rica: 51.6\% of the voters said 'yes' to Costa Rica joining CAFTA. This popular mobilisation had a strong impact not only among Costa Ricans but also in the whole region. The anti-colonialism rhetoric had a different effect in the two regions analysed in this paper. In Central America, the US is perceived as the neo-coloniser, while Europe's role is perceived mostly in terms of cooperation and solidarity, given its role during the peace-building and democratisation process of the 80s and 90s. Though Europeans were represented as colonisers, this tendency was much stronger in West Africa. 
Convergence for Effective Voice?

Convergence is sought to enable a more effective voice, supporting Magis findings (2010). However, in the case of the EPAs campaign, it is unclear whether the use of the slogan with the ambiguity described above led to better results. The confusion created about the message discouraged some policymakers from engaging in dialogue. Many perceived all groups, however, critical, to be one big anti-negotiations group. A common view expressed in several interviews was, "They were against negotiations anyways and closed to dialogue." In the case of other policymakers, especially those from ACP countries, the STOP EPAs (short slogan) was used as a tool to increase pressure on European negotiators, based on the view that the agreement was politically costly for them. As reported during the interviews, this created confusion among policymakers, and European negotiators in particular felt that the proposals were not constructive. The perceived need for convergence among activists led to some shared views on the lowest common denominators which reflected common basic concernsthe development dimensions of EPAs, rather than common policy proposals.

\section{Conclusions}

This article explored the alleged emancipatory potential of GCS by examining transnational activism in relation to trade negotiations. This potential is realised through the expression of different ideas of fair trade and the process of managing diversity of opinions while searching for common messages and an enhanced voice. Transnational activists' actions led to more reflection and debate on negotiations which are often outside the scrutiny of citizens due to them being highly technical. This can, in itself, be emancipatory, especially for what it means for groups whose voices are often neglected. The process of enabling people to be heard involved intensive discussions in the search for a common voice. However, only common concerns were shared and expressed.

Instead, groups consistently managed the tension between reform and resistance. This was not an either/or dilemma. Reformists believed they were resisting, and resisters cooperated to achieve 'a lesser evil'. In a context of perceived weaknesses and lack of mobilising utopias, groups found incentives for collaboration despite their differences. Though, there was fluid communication among groups, interactions within the coalitions have been described as not always easy and free of obstacles. Interviewees referred to heated debates when agreeing on common messages and actions. Most challenges to the market liberalist EU approach have been centred around the pace and scope of liberalisation to avoid possible negative social and environmental effects of liberalisation. To some extent, only a few alternatives at the systemic level have been explored, such as that of the 'good life' which highlights the ecological limits to growth. New ways of thinking, which transcend our current patterns of consumption and production, remain marginal. Rather than new options as a result of increased interactions among different groups, we observed a coexistence of a range of options, some more defined than others. Future research needs to deepen analysis of the facilitating and constraining factors for joint campaigns, despite ideological diversity. 
Transnational activism is characterised by coalitions which were composed of diverse groups acting in the 'North' and in the 'South', and which adopted different advocacy approaches. It appears as if transnational campaigns related to NorthSouth bilateral/biregional agreements would need a composite structure both in terms of location and strategies. The term 'transnational composite activism' could summarise the way this type of coalition operates. Groups profit from their joint work and, at the same time, they need to work out their differences. They are composite as they are composed of sub-parts or sub-campaigns in terms of types and levels of actions. They combine both dialogue and a contentions type of advocacy at national and regional levels in both the 'North' and the 'South'. These separate but coordinated actions represent a certain division of roles. Despite their differences, perceived benefits are access to information, access to resources and the expectation of enhanced impact. Efforts were made to achieve convergence to increase voice as Magis (2010) suggests, but this was temporary and was limited to a few groups. These special characteristics are important as they shape new forms of transnational activism, which imply less clear effects than are often portrayed.

The effects of joint but conflicting messages means advocacy needs to be explored in more detail. Converging on common messages or concerns increases the visibility of the concerns and the public pressure in policymakers' eyes, but it does not necessarily lead to deeper dialogue on the underlying assumptions and causes of poverty, inequality and injustice. The assumption that the impact would be greater if more groups were to become involved needs to be examined in more detail. There is also a need to study the effects of watered-down and ambiguous messages.

These findings contribute to problematising the idea of GCS as a realm of takenfor-granted emancipatory potentials. The emancipatory contents and meanings are being forged through conflicts and interactions among different groups. Some ideas become predominant, while others remain marginalised. Though it is true that activists overcome their differences and find points of convergence, this is not always easy and does not always mean that conflicts are solved. GCS is a realm where discursive struggles continue to take place over the meanings of a 'good' global society. It is a space where different agendas meet and interact, rather than being a channel where a single agenda is wished for. However, it is through the process of negotiations and the creation of spaces for participation that the emancipatory potentials of GCS are partly, and promisingly, being realised.

Acknowledgments I am grateful to interviewees and organisations which collaborated with data gathering and analysis, especially Oxfam Novib and CIFCA. I thank Prof. Paul Hoebink, Dr. Kees Biekart, Willem Elbers, Sara Kinsbergen, participants of the International Society for Third-Sector Research (ISTR) 9th International Conference in Istanbul in July 2010 and anonymous reviewers for their useful comments for improvement. I thank Carolina Orloff and Howard Turner for proof-reading the manuscript. Finally, I acknowledge the financial support of the Dutch Ministry of Foreign Affairs for my $\mathrm{PhD}$ research through the IS-Academy Programme.

Open Access This article is distributed under the terms of the Creative Commons Attribution Noncommercial License which permits any noncommercial use, distribution, and reproduction in any medium, provided the original author(s) and source are credited. 


\section{Annex 1. Acronyms}

\begin{tabular}{ll}
\hline ACP & African, Caribbean and Pacific Group \\
AdAs & Association Agreement, in Spanish: Acuerdo de Asociación \\
ALCA & The Free Trade Area of the Americas, in Spanish: Área de Libre Comercio de las Américas. \\
CAFTA & Dominican Republic_Central America Free Trade Agreement \\
DG-Trade & Directorate General of Trade (European Commission) \\
EU & European Union \\
ESCR & Economic Social and Cultural Rights \\
EPAs & Economic Partnership Agreements \\
ECOWAS & Economic Community of West African States \\
FTAs & Free trade agreements \\
GCS & Global civil society \\
NAFTA & North America Free Trade Agreement \\
UNCTAD & United Nations Conference on Trade and Development \\
WTO & World Trade Organisation
\end{tabular}

\section{Annex 2. Key events and actions (2004-2009)}

\section{4}

January 2004. Briefing paper by CONCORD on EPAs

October 2004. Launch of the STOP EPAs Campaign at the European Social Forum in London and at the African Social Forum in Lusaka

November 2004. Publication of paper 'Six Reasons to Oppose EPAs in their Current Form' signed by European and African networks

\section{5}

February 2005. Action Aid publishes report on EPAs

April 2005. Participation in Joint Parliamentary Assembly in Bamako. A speech is delivered by a Ghanaian trade union leader

July 2005. Representatives of the West African Trade Union Working group on Trade and Development meet officials of ECOWAS and the EU

December 2005. Events and demonstrations at the WTO Hong Kong Ministerial Meeting 2006

February 2006. Presentation of study by ECDPM 'Alternatives (to) EPAs', commissioned by Oxfam March 2006. Africa Trade Network launches global call for action against EPAs

April 2006. ROPPA issues proposal

April 2006. 2nd ACP Civil Society Forum in Brussels, Belgium

May 2006. People's Summit in Vienna, Austria. 'Enlazando Alternativas 2'

27 September 2006. STOP EPAs Day. Actions in various locations

Launch of Briefing Paper 'Unequal Partners' by Oxfam International

October 2006. Farmers and workers tour Europe

October 2006. Workshop hosted by South Centre and co-organised with 11 NGOs

October 2006. Demonstrations and workshops in Niamey, Niger

2007

January 2007. Various activities at the World Social Forum in Nairobi, Kenya. Collection of signatures 
Annex 2 continued

March 2007. Meeting of organisations with EU Development Ministers in Bonn, Germany

April 2007. E-mail action-21,000 people sent an email to Merkel. Day of Action targeting the German government (German Presidency of the EU)

April 2007. 'A Matter of Political Will' discussion paper is published jointly by Oxfam International and Third World Network Africa

May 2007. STOP EPAs March organised in Abuja, Nigeria. The Nigeria Labour Congress estimates 10,000 participants

27 September 2007. STOP EPAs Day. Actions in various locations. 60,000 signatures collected in Spain alone

November 2007. Negotiations start on an Association Agreement with Central America. CIFCA and partners issue a policy paper analysing possible negative effects for vulnerable groups

December 2007. Civil Society Forum and related events during the AU-EU Summit in Lisbon, Portugal

2008

January 2008. Demonstrations in Dakar, Senegal and Brussels, Belgium by 3,000 people in each case

9 April 2008. Public debate at the European Parliament and demonstration outside the European Commission in Brussels, Belgium

April 2008. Various actions at XII UNCTAD Conference in Accra, Ghana. Presentation of 'Partnership or Power-play'

May 2008. People's Summit in Lima, Peru. 'Enlazando Alternativas 3'

Publication of 'Dialogue of the Deaf' by ICCO

10 July 2008. Meeting in Brussels of European and Latin American networks and coalitions working on Association Agreements

September 2008. Actions on the occasion of the 6th ACP Ministerial Meeting in Accra, Ghana, including a caravan travelling across Benin, Togo and Ghana

2009

28 January 2009. Public Debate at the European Parliament organised by CIFCA and Grupo Sur in Brussels, Belgium

27 March 2009. Sensitisation workshops of the campaign 'El Agua fuera del Ada' in Tegucigalpa, Honduras (Water outside AdAs) organised by Hemispheric Social Alliance, Foro del Agua with the support of Heinrich Boll Foundation and Oxfam Novib

30-31 March 2009. Public Forum, meetings with parliamentarians and demonstration outside the hotel where VII round of negotiations were being held in Tegucigalpa, Honduras. Coordinated by CHAAC

16 October 2009. Public forum and debate at the Swedish Parliament on Association Agreements organised by CIFCA and its Swedish members and partners

May 2010. Association Agreement with Central America is signed in Madrid, Spain. Activists demand that parliaments do not ratify the agreement

2009

May 2010. Association Agreement with Central America is signed in Madrid, Spain. Activists demand that parliaments do not ratify the agreement

\section{References}

Africa Trade Network. (2006). Declaration of 9th Annual Meeting of the Africa Trade Network. Forward with the Struggle to STOP the EPAs. http://www.twnafrica.org/index.php?option=com content \&view=article \&id=86:declaration-of-9-annual-meeting-of-the-africa-trade-network- $\&$ catid=47: atn\&Itemid=72. Accessed March 23, 2011. 
Action Aid, Christian Aid, Oxfam. (2008). Manual on EU FTAs. Eight briefings on the European Union's approach to Free Trade Agreements. http://www.oxfam.org.uk/resources/policy/trade/euftamanuals. html. Accessed March 23, 2011.

Amoore, L., \& Langley, P. (2004). Ambiguities of global civil society. Review of International Studies, 30, 89-110.

Anderson, K., \& Rieff, D. (2005). Global civil society: A sceptical view. In H. Anheier, M. Glasius, \& M. Kaldor (Eds.), Global civil society 2004/5. London: Sage Publications.

Anheier, N., Glasius, M., \& Kaldor, M. (Eds.). (2001). Global civil society yearbook 2001. Oxford: Oxford University Press.

Bebbington, A., Hickey, S., \& Mitlin, D. (Eds.). (2008). Can NGOs make a difference? The challenge of development alternatives. London: Zed Books.

Berry, C., \& Gabay, C. (2009). Transnational political action and 'global civil society' in practice: The case of Oxfam. Global Networks, 9(3), 339-358.

Beyers, J. (2004). Voice and access. Political practices of European Interest Associations. European Union Politics, 5(2), 211-240.

Bilaterals, BIOTHAI and GRAIN. (2008). Fighting FTAs: the Growing Resistance to Bilateral Free Trade and Investment Agreements, On-line document: Bilaterals. http://www.fightingftas.org/ and http//www.bilaterals.org. Accessed March 23, 2011.

Bond, P. (2006). Civil society on global governance: Facing up to divergent analysis, strategy and tactics. Voluntas, 17, 359-371.

CIFCA. (2009). Open Letter Commissioner Ashton 2009. http://www.cifca.org/0901_VI_ronda_FINAL_ eng1.pdf. Accessed March 23, 2011.

Colas, A. (2004). Global civil society: Analytical category or normative concept? In D. Chandler \& G. Baker (Eds.), Global civil society: Contested futures. London: Routledge.

Della Porta, D., \& Tarrow, S. (Eds.). (2005). Transnational protest and global activism (people, passions, and power). Oxford: Rowman and Littlefield Publishers.

Desai, M., \& Said, Y. (2003). Trade and global civil society: The anti-capitalist movement revisited. In M. Kaldor, H. Anheier, \& M. Glasius (Eds.), Global civil society. Oxford: Oxford University Press.

Dryzek, J. (2006). Deliberative global politics, discourse and democracy in a divided world. Cambridge: Polity Press.

Dür, A., \& De Bièvre, D. (2007). Inclusion without influence? NGOs in European trade policy. Journal of Public Policy, 27(1), 79-101.

ECDPM. (2006). Policy Management Report 11: Alternative (to) EPAs Possible Scenarios for the Future ACP Trade Relations with the EU. Maastricht: ECDPM. http://www.ecdpm.org/. Accessed March 23, 2011.

Edwards, M., \& Gaventa, J. (2001). Global citizen action. Boulder: Lynne Reinner Publishers, Inc.

Elbers, W., \& Schulpen, L. (2010). Decision making in partnerships for development: Explaining the influence of local partners. Nonprofit and Voluntary Sector Quarterly. doi:10.1177/08997640 10366304.

Enlazando Alternativas. (2010). Final Declaration Madrid, 16 May 2010. http://www.enlazandoalternativas. org/IMG/pdf/Declaracion_Final_Cumbre.pdf. Accessed March 23, 2011.

EPAs Coalition. (2006). Harare declaration. A global call for action to Stop EPAs. http://www.twnafrica. org/index.php?option=com_content\&view=article\&id=132:harare-declaration-a-global-call-for-actionto-stop-epas\&catid=47:atn\&Itemid=72. Accessed March 23, 2011.

EPAs Coalition. (2004). Position statement six reasons to oppose EPAs in their Current Form, November 2004, signed by Action Aid, Africa Trade Network, Agir Ici, Both ENDs, CAFOD, Christian Aid, ENDA, Eurostep, EcoNews Africa, Mwengo, Oxfam, SEATINI, Traidcraft, TWN Africa, 11.11.11. http://www.stopepa.de/img/six-questions-on-epas.pdf. Accessed March 23, 2011.

EPAs Coalition 2. (2007a). STOP EPAs day statement, 27 September 2007. www.foeeurope.org/ publications/2007/StopEPAs_JointStatement_270907_en.pdf. Accessed December 4, 2009.

EPAs Coalition 2. (2007b). STOP EPAs day statement, 14 April 2007. www.stopepas.de. Accessed December 4, 2009.

European Union, European Commission. (2006). Global Europe: Competing in the World. http://trade. ec.europa.eu/doclib/docs/2006/october/tradoc_130376.pdf. Accessed March 23, 2010.

Faber, G., \& Orbie, J. (2008). The new trade and development agenda of the European Union. Perspectives on European Politics and Society, 9(2), 192-207.

Falk, R. (1999). Global civil society: Perspectives, initiatives, movements. In R. Falk (Ed.), Predatory globalisation: A critique. Cambridge: Polity Press. 
Florini, A. (2000). The third force. The rise of transnational civil society. Carnegie Endowment for International Peace and Japan Centre for International Exchange.

Gaventa, J. (2006). Finding the spaces for change: A power analysis in power, exploring power for change, IDS Bulletin 37.6. Brighton: IDS.

Kaldor, M. (2003). Global civil society: An answer to war. Cambridge: Polity Press.

Katz, H. (2006). Gramsci, Hegemony, and global civil society networks. Voluntas, 17, 333-348.

Keane, J. (2003). Global civil society. Cambridge: Cambridge University Press.

Lipschutz, R. (1992). Reconstructing world politics: The emergence of civil society. Millennium, 21(3), $389-420$.

Magis, K. (2010). Convergence: Finding collective voice in global civil society. Voluntas, 21(3), 317-338.

Manji, F. \& O'Coill, C. (2002). The missionary position: NGOs and development in Africa. London: Fahamu. http://www.fahamu.org/downloads/missionaryposition.pdf. Accessed May 17, 2010.

Mati, J. (2009). A cartography of a global civil society advocacy alliance: The case of the global call to action against poverty. Journal of Civil Society, 5(1), 83-105.

Munck, R. (2006). Global civil society: Royal road or slippery path? Voluntas, 17, 325-332.

Nelson, P., \& Dorsey, E. (2007). New rights advocacy in a global public domain. European Journal of International Relations, 13(2), 187-216.

Newell, P., \& Tussie, D. (2006). Civil society participation in policy-making in Latin America: Reflections and lessons. Sussex: IDS.

Salamon, L., Sokolowski, W., and associates. (2004). Global Civil Society: Dimensions of the Nonprofit Sector (Vol. 2). Bloomfield, CT: Kumarian Press.

Salamon, L., Sokolowski, W., \& List, R. (2003). Global civil society, an overview, centre for civil society studies. Baltimore, MD: The Johns Hopkins University.

Scholte, J. A. (2005). Civil society and democracy in global governance. In R. Wilkinson (Ed.), The global governance reader. London: Routledge.

Spalding, R. (2007). Civil society engagement in trade negotiations: CAFTA opposition movements in El Salvador. Latin American Politics and Society, 49(4), 85-114.

Tarrow, S. (2005). The new transnational activism. New York: Cambridge University Press.

Taylor, R. (2002). Interpreting global civil society. Voluntas, 13(4), 339-347.

Taylor, R., \& Naidoo, K. (2004). Taking global civil society seriously. In R. Taylor (Ed.), Creating a better world: Interpreting global civil society. Bloomfield, CT: Kumarian Press.

UNCTAD. (2007). Unctad Trade and Development Report 2007: Regional Cooperation for Development. Geneva: UNCTAD. http://www.unctad.org/en/docs/tdr2007_en.pdf. Accessed March 23, 2010.

Wade, R. (2010). Does trade liberalization contribute to economic prosperity? In P. Haas \& J. Hird (Eds.), Controversies in globalization. New York: Congressional Quarterly Press, Sage.

Waterman, P. (2005). Global civil society: A concept worth defining, a terrain worth disputing. Network Institute for Global Democratisation (NIGD). http://www.nigd.org/docs/GlobalCivilSociety PeterWatermanNovember2005. Accessed May 5, 2010. 